\title{
AN ANALYSIS OF STEEL SLAG AND ITS USE IN ACID MINE DRAINAGE (AMD) TREATMENT ${ }^{1}$
}

\author{
Ben Mack and Brady Gutta ${ }^{2}$
}

\begin{abstract}
Steel slag is a highly alkaline substance that is a byproduct of the steelmaking process. This substance has been used in many different applications, including the remediation of mine drainage. However, some research has shown that large concentrations of possibly toxic metals may leach from the steel slag matrix when it is used in this capacity.

The National Mine Land Reclamation Center (NMLRC) has used steel slag in three Acid Mine Drainage (AMD) remediation projects. These three projects are named the McCarty Highwall site, the DeAntonis site, and the Muzzleloader Club site. Two of the three projects used steel slag in similar capacities. The DeAntonis site and the Muzzleloader Club site used steel slag in direct contact with fresh water, while the slag used at McCarty Highwall site was directly contacted by acidic water. Although project longevity between the three projects varied, leaching potential of toxic metals did not seem to be affected by the type of water the steel slag was used in. All three projects have also shown water quality improvement regardless of time since project construction.
\end{abstract}

Although both the McCarty Highwall and Muzzleloader Club projects had a few elements above EPA CCC standards, it is likely that these concentrations are not significantly high enough to greatly affect water quality. Due to a general lack of TCLP metals found in effluent waters for these projects, steel slag is recommended as a viable alkaline source for the treatment of AMD.

Additional Key Words: Alkalinity sources, limestone, trace metals

1 Paper was presented at the 2009 National Meeting of the American Society of Mining and Reclamation, Billings, MT Revitalizing the Environment: Proven Solutions and Innovative Approaches May 30-June 5, 2009. R.I. Barnhisel (Ed.) Published by ASMR, 3134 Montavesta Rd., Lexington, KY 40502.

${ }^{2}$ Ben Mack is a Research Associate, West Virginia University, Morgantown, WV 26506. Brady Gutta is a Project Manager, West Virginia University, Morgantown, WV 26506.

Proceedings America Society of Mining and Reclamation, 2009 pp 722-742 DOI: $10.21000 / J A S M R 09010722$

http://dx.doi.org/10.21000/JASMR09010722 


\section{$\underline{\text { Introduction }}$}

Steel slag is defined as the leftover solid substance resulting from steel-making. This material is composed of the impurities removed from the steel, as well as the flux material (typically limestone and/or dolomite) used in the steel-making process. The Ca compounds in the flux complex with $\mathrm{Al}$, silicon, and $\mathrm{P}$ impurities to form slag. This substance floats to the top of the molten iron and is placed into large piles. Although slag forms at 2,700 degrees F, it quickly cools and becomes a glassy solid (Ziemkiewicz, 1998).

In addition to the use of steel slag as acid mine drainage treatment, it is also used as a soil amendment to correct acidic soils, as ballast for railroads, and in road construction. Although the amounts of impurities within the slag may differ, composition of steel slag is similar among the different types. An example of the chemical makeup of a typical steel slag sample is shown in Table 1 (Hamilton et al., 2007).

Table 1. Typical chemical analysis of steel slag by percentage.

\begin{tabular}{cc}
\hline Constituent & Percent of total \\
\hline Aluminum oxide & $6.93 \%$ \\
Calcium oxide & $35.41 \%$ \\
Iron oxide & $19.24 \%$ \\
Magnesium oxide & $7.81 \%$ \\
Silicon dioxide & $14.58 \%$ \\
Carbon & $0.3 \%$ \\
Sulfur & $0.21 \%$ \\
Phosphorus & $0.18 \%$ \\
\hline
\end{tabular}

Steel slag also consists of several different types of heavy metals in various concentrations. A typical Toxicity Characteristics Leachate Procedure (TCLP) analysis for steel slag is illustrated in Table 2 (Hamilton et al., 2007). The TCLP analysis was developed by the EPA in order to determine the mobility of various analytes, as well as to see if these analytes meet the EPA definition of toxicity (US Environmental Protection Agency, 1992). 
Table 2. Typical TCLP analysis of steel slag.

\begin{tabular}{ccc}
\hline Element & $\begin{array}{c}\text { Amount in steel slag } \\
(\mathrm{mg} / \mathrm{L})\end{array}$ & $\begin{array}{c}\text { EPA maximum allowed } \\
\text { concentration in leachate } \\
(\mathrm{mg} / \mathrm{L})\end{array}$ \\
\hline Arsenic & $<0.002$ & 5.0 \\
Barium & 1.4 & 100.0 \\
Cadmium & $<0.002$ & 1.0 \\
Chromium & $<0.038$ & 5.0 \\
Lead & $<0.004$ & 5.0 \\
Mercury & $<0.0$ & 0.2 \\
Selenium & $<0.003$ & 1.0 \\
\hline
\end{tabular}

Steel slag may also contain other heavy metals, including: $\mathrm{Sb}, \mathrm{Cu}, \mathrm{Mn}, \mathrm{Mo}, \mathrm{Ni}, \mathrm{Ag}, \mathrm{Tl}, \mathrm{Sn}$, $\mathrm{V}$, and $\mathrm{Zn}$. There is some concern that these elements may leach from steel slag if slag is used in AMD treatment. This issue will be discussed in more detail later in this paper.

There has been a great deal of previous research on steel slag and its uses in the field of AMD remediation. Bowden et al. (2006) found that rapid iron removal was possible using steel slag. The water tested in this research was circumneutral with low iron concentrations. Four different sizes of steel slag were used, as well as $20 \mathrm{~mm}$ basalt and a control, to determine if the surface of steel slag would provide the proper media for Surface Catalyzed Oxidation of Ferrous Iron (SCOOFI). Although it was impossible to tell which reactor performed the best, the researchers found that all steel slag and basalt reactors had iron removal rates of $>80 \%$, while the control reactor had a removal rate of $45 \%$. The authors concluded that for mine waters with low initial concentrations of iron, steel slag provided a suitable surface for SCOOFI to occur.

Other steel slag research has focused specifically on treatment of AMD in discharges with greater metal concentrations. Laverty et al. (2007) used 10,000 tons of steel slag to treat several different AMD discharges from the abandoned Broken Aro mine in the Little Raccoon Creek watershed in Ohio. Steel slag was used in several different neutralization operations in this project. In the Flint Run East and Flint Run West drainages, it was used as part of a limestone leach bed and a vertical flow pond, respectively. AMD that was pre-treated by other passive systems flowed into this leach bed as a polishing step before the water was discharged into the receiving stream. This is different from the way that steel slag is normally used. Typically, freshwater contacts steel slag, which creates high $\mathrm{pH}$ water that is then mixed with AMD. The third phase of the Broken Aro mine project, known as Salem Road, mixed steel slag with fresh 
water and used it as a core for two limestone dams. Four of the five AMD sites are now discharging alkaline water and there has been an overall decrease of $98 \%$ of the acid load from the Broken Aro mine.

Two other remediation projects using steel slag were completed in the Huff Run watershed in southeastern Ohio (Hamilton et al., 2007). The Lindentree site used steel slag bedded open limestone channels. In addition to adding more alkalinity to the discharge than limestone alone, it was also expected that the use of steel slag would lengthen the life of the channel. Discharge from the Lindentree site currently has no acidity, $80-100 \mathrm{mg} / \mathrm{L}$ of alkalinity, and $0.2 \mathrm{mg} / \mathrm{L}$ of iron. The Lyons project used steel slag in impoundments and open limestone channels to increase alkalinity generation. Due to the combination of steel slag and other passive treatment systems, discharge from this site has shown large improvements in water quality. These improvements are detailed in Table 3.

Table 3. Changes in water quality for the Lyons site.

\begin{tabular}{cccc}
\hline Parameter & Unit & Pre-construction & Post-construction \\
\hline $\mathrm{pH}$ & $\mathrm{SU}$ & 3.10 & 6.33 \\
Acidity & $\mathrm{mg} / \mathrm{L}$ as CaCO & 209.4 & 17.7 \\
Alkalinity & $\mathrm{mg} / \mathrm{L} \mathrm{as} \mathrm{CaCO} 3$ & 0.0 & 20.1 \\
Iron & $\mathrm{mg} / \mathrm{L}$ & 33.8 & 14.1 \\
Aluminum & $\mathrm{mg} / \mathrm{L}$ & 23.2 & 3.0 \\
Manganese & $\mathrm{mg} / \mathrm{L}$ & 8.7 & 0.0 \\
\hline
\end{tabular}

Other research has focused on possible environmental impacts of the use of steel slag. There are two main potential environmental liabilities when using steel slag. These are: $\mathrm{pH}$ that is too high (11-12 SU), and the potential of toxic trace metals to leach from the steel slag matrix. In the case of using steel slag to treat AMD, the steel slag is usually mixed with pre-existing fresh water and then mixed with the AMD that needs treated (Ziemkiewicz and Skousen, 1998). By the time this water is discharged into a receiving stream, the water is circumneutral.

The possibility that toxic metals may become mobile in the environment when steel slag is used has been extensively researched (Fallman, 2000; Proctor et al., 2002). However, no consensus has yet been reached because there is conflicting research on this issue. Chaurand et al. (2006) looked at the leachability of Cr and V from Blast Oxygen Furnace (BOF) steel slag. They found that the amount of both $\mathrm{Cr}$ and $\mathrm{V}$ that leached from the steel slag was dependent on 
the speciation of the metal. There was less $\mathrm{Cr}$ found in the leachate, and the majority of it was in the less toxic and less mobile trivalent form. Vanadium, by contrast, was found to have significantly high concentrations and it was found mostly in the more toxic pentavalent form, even though it is originally found in the steel slag matrix in the +4 form.

Other studies have shown very low metal concentrations in leachate from steel slag. Research performed by Gomes and Pinto (2006) performed leaching tests on Electric Arc Furnace (EAF) slag and ladle slag (slag that underwent continued refining in the ladle). They also attempted to determine if the age of the slag influenced the rate of metal leaching. Neither the EAF nor the ladle slag violated the "Inert" leach water quality criteria for the tested metals. However, the rate of leaching did change with slag age, with older slag releasing more metals. Even though leaching rates increased over time, overall metal concentrations in the leachate remained low. For example, $\mathrm{Ca}$ and $\mathrm{Mg}$ made up $0.5 \%$ of the leachate, while all other metals were below $0.05 \%$. These findings are particularly relevant to the treatment of AMD because EAF slag is typically used in the construction of AMD remediation projects.

In an attempt to remediate the Allegheny Portage Railroad site in Pennsylvania, Cravotta (2005) also evaluated leaching of steel slag by AMD, and presented chemical and mineralogical analysis of the slag. Leachate results were compared with USEPA (2002) criteria continuous concentration (CCC) values for protection of freshwater organisms and with mine effluent standards. Cravotta found that steel slag could be a viable alternative for treatment at this site, particularly if used in conjunction with other treatment technologies.

Another study performed by Proctor et al. (2000) compared the chemical and physical characteristics of steel slag from all three types of furnaces. They found that none of the TCLP metals, with the exception of $\mathrm{Ba}$ and $\mathrm{Mn}$, had significantly high concentrations in the leachate of any of the slag samples. However, none of the metals had greater concentrations than the TCLP standards put forth by the EPA. The authors also compared the concentrations of metals found in the slags against the concentrations of those same metals found in natural soil. Each slag contained levels of metals significantly higher than those found in natural soil. In the case of EAF slag, these metals were: $\mathrm{Sb}, \mathrm{Cd}, \mathrm{Cr}^{6+}$ and total $\mathrm{Cr}, \mathrm{Cu}, \mathrm{Mn}, \mathrm{Mo}, \mathrm{Ni}, \mathrm{Se}, \mathrm{Ag}, \mathrm{Sn}, \mathrm{V}$, and $\mathrm{Zn}$. Although $29 \%$ of the EAF slag samples had $\mathrm{Cr}^{6+}$ found in them, these levels were still below EPA limits for soil. 


\section{Objective}

The objective of this paper is to determine the viability of steel slag as a treatment technology for AMD. The West Virginia Water Research Institute (WVWRI) has used EAF steel slag in several different AMD remediation projects. These projects are: McCarty Highwall (Beaver Creek of the Cheat River), the DeAntonis property (Morgan Run of the Cheat River), and the Muzzleloader Club project (Lambert Run of the West Fork River).

\section{McCarty Highwall}

\section{$\underline{\text { Site Description }}$}

The McCarty Highwall is an abandoned surface, and possibly underground, mine site located about 10 miles southeast of Bruceton Mills in Preston County, West Virginia. Prior to construction at McCarty, water seeping out along an old spoil pile was flowing into a channel and mixing with a second spoil seep approximately $500 \mathrm{ft}$ downstream. These two seeps form a small stream that flows south into Beaver Creek and eventually into the Cheat River. Along the way, the stream picks up several other small AMD seeps. A 1997 reconnaissance study by the Corps of Engineers showed the first seep was moderately acidic with a $\mathrm{pH}$ of 4.1 and a net acidity of $27.5 \mathrm{mg} / \mathrm{L}$. The second seep was similar with a $\mathrm{pH}$ of 3.9 and $24.5 \mathrm{mg} / \mathrm{L}$ acidity.

The West Virginia Water Research Institute also performed pre-construction sampling at this site. Flows were measured by stretching a measuring tape across the width of the discharge and dividing the stream into sections. Each section was between 10 to $20 \%$ of the overall width of the discharge, so there were at least 5 measurement points for each discharge. Depth at each sampling point was measured using the 0.6 depth method (Buchanan and Somers, 1976). Velocity at each sampling point was found using a Marsh-McBirney Flo-Mate 2000 (MarshMcBirney, Frederick, MD). The width interval, depth, and velocity were multiplied together at each point in order to determine flow. Total flow for the discharge was found by adding the flow values from each sampling section together.

Water $\mathrm{pH}$, conductivity, DO, and temperature were determined in the field using an YSI 556 multiprobe. Lab analyses included acidity (EPA method 305.2), alkalinity (EPA method 310.1), pH (EPA method 150.1), conductivity (EPA method 120.1), and sulfate (EPA method 200.7). $\mathrm{Fe}, \mathrm{Al}, \mathrm{Mn}, \mathrm{Ca}$, and $\mathrm{Mg}$ were all determined using EPA method 200.7. Trace metals were also determined using EPA method 200.7. Two water samples were taken at each sample point: (I) a 250-mL unfiltered sample was taken for general water chemistry $\mathrm{pH}$, total acidity and alkalinity 
by titration, and sulfate); and (II) a $25-\mathrm{mL}$ sample filtered with a 0.45 micrometer Nalgene syringe filter was acidified to $\mathrm{pH}$ of $<2$ with $0.5 \mathrm{ml}$ concentrated nitric acid and used to determine metal concentrations.

Due to the acidity of the on-site AMD sources and the presence of additional acid sources downstream, limestone treatment was insufficient. A stronger alkalinity source was needed: one that would raise the alkalinity of the on-site water to levels that would neutralize additional AMD entering the stream downstream and one that would last for at least 10 years with very little maintenance. Earlier studies with steel slag indicated its suitability for such situations (Simmons et al., 2002).

In October 2000, a series of open limestone channels (OLCs) and steel slag leach beds were installed downstream of seeps 1 and 2. All four OLCs were constructed with a limestone sand liner and 6-8" limestone rocks. The leach beds consisted of a settling basin and steel slag check dam. Both check dams were formed from 150 tons of steel slag and rip rapped along the upstream side with 6-8" limestone rocks. A $200 \mathrm{ft}$ open limestone channel (OLC \#1) was constructed from the upper spoil seep to the edge of the first settling basin. A secondary OLC (OLC \#1b) was constructed to the stream right side of OLC \#1 to carry AMD from an intermittent spoil seep to the first basin. Water flows from the basin through the center of a steel slag check dam and enters a $300 \mathrm{ft}$ open limestone channel (OLC \#2). OLC \#2 exits into a limestone gravel area along the edge of the second settlement basin. AMD from the downstream seep flows from the left of basin \#2 through a $100 \mathrm{ft}$ open limestone channel (OLC \#3) and exits into the gravel area at the edge of the second settling basin. Water enters into settling basin \#2 from OLCs \#2 and \#3 and exits the system through a second steel slag check dam and forms the headwaters of an unnamed tributary of Beaver Creek. Figure 1 is a rendering of the overall design of the McCarty Highwall AMD treatment project and Fig 2 is a picture of steel slag leach bed \#1 and OLC \#1. 


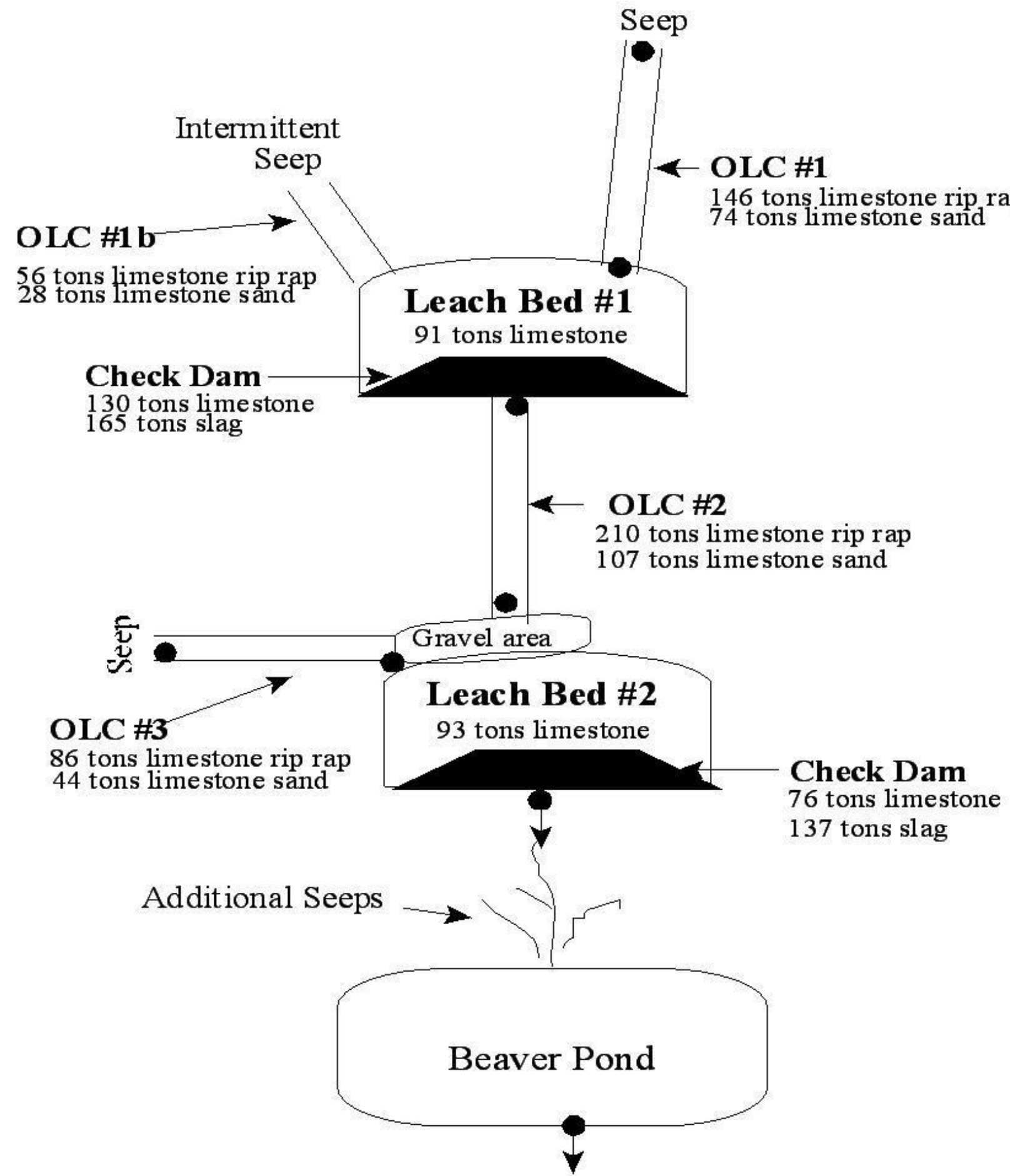

Figure 1. Design of the McCarty Highwall AMD treatment project 


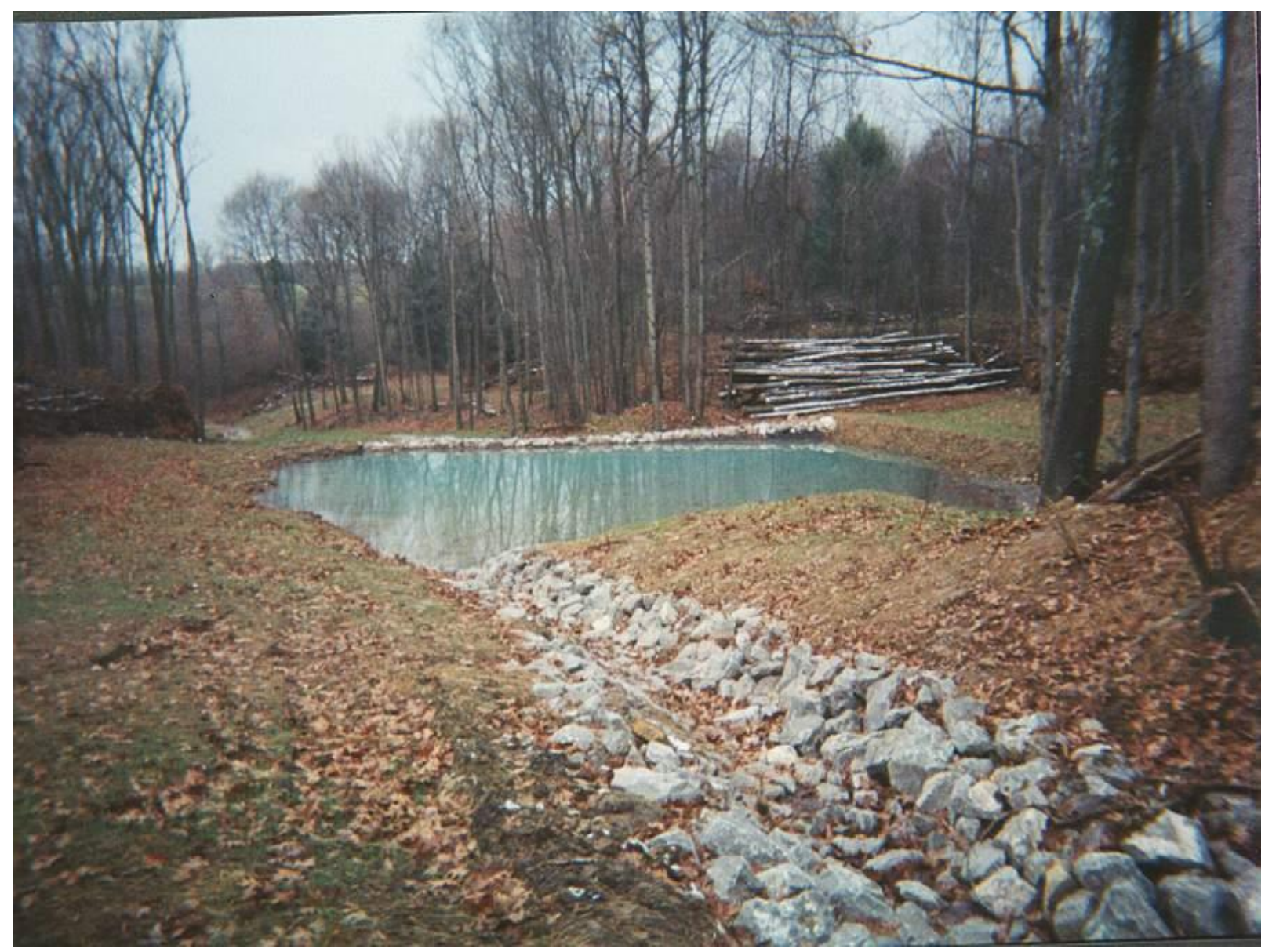

Figure 2. Leach bed \#1 and OLC \#1 at the McCarty Highwall AMD treatment project

McCarty Highwall was one of the first AMD treatment projects that WVWRI attempted. When the project was built in 2000, steel slag had not been extensively studied. Because of this, steel slag was used in a different way in this project than in future AMD reclamation (Simmons et al., 2002). Instead of using fresh water, steel slag came into direct contact with AMD. This caused the dissolved $\mathrm{Al}$ in the AMD to precipitate on to the slag, which in turn caused the slag to harden to the consistency of concrete. The steel slag in the limestone dams was also open to the atmosphere. As the steel slag was exposed to water and $\mathrm{CO}_{2}$ in the atmosphere, calcite formation occurred and the slag particles began to cement together. Surface area and porosity of the slag was reduced, giving a lesser area for alkalinity generation to take place. Because of this, in July 2004, 150 more tons of steel slag was added to both leach beds to recharge the alkalinity generation ability of the system. The addition of more steel slag allowed the system to continue to neutralize acid load at a high level. 


\section{$\underline{\text { Water Quality }}$}

After the construction of the McCarty Highwall AMD treatment project, water quality was sampled post-construction to determine compliance with water quality standards. Normally, a standard suite of parameters is monitored after construction. Some of these include: acidity, alkalinity, $\mathrm{pH}$, conductivity, $\mathrm{SO}_{4}{ }^{2-}, \mathrm{Ca}, \mathrm{Mg}, \mathrm{Fe}, \mathrm{Al}$, and $\mathrm{Mn}$. However, since this was one of the first AMD treatment projects constructed by WVWRI using steel slag, water samples were also analyzed for elements listed in the EPA's TCLP list. Table 4 shows mean values for traditional AMD parameters and Table 5 gives mean TCLP metal concentrations for the McCarty Highwall project. The sample site was 0.25 miles downstream of the discharge from the project site.

Table 4. Mean values for traditional AMD parameters, except for $\mathrm{pH}$. The median value was used for $\mathrm{pH}$. Results in bold are greater/less than the EPA's CCC standard for that parameter. $\mathrm{NR}=$ not regulated by the EPA under $\mathrm{CCC}$ standards.

\begin{tabular}{ccccccccc}
\hline & Flow & $\mathrm{pH}$ & Acidity & Alkalinity & $\mathrm{SO}_{4}$ & $\mathrm{Fe}$ & $\mathrm{Al}$ & $\mathrm{Mn}$ \\
\hline & $\mathrm{gpm}$ & $\mathrm{SU}$ & $\mathrm{mg} / \mathrm{L}$ & $\mathrm{mg} / \mathrm{L}$ & $\mathrm{mg} / \mathrm{L}$ & $\mathrm{mg} / \mathrm{L}$ & $\mathrm{mg} / \mathrm{L}$ & $\mathrm{mg} / \mathrm{L}$ \\
\hline Sample value & 137.2 & $\mathbf{6 . 4}$ & 4.4 & 15.6 & 148.5 & 0.6 & $\mathbf{0 . 3}$ & $\mathbf{0 . 5}$ \\
EPA standard & $\mathrm{NR}$ & $6.5-9$ & $\mathrm{NR}$ & 20 & 250 & 1 & 0.09 & 0.05 \\
\# of samples & 46 & 67 & 67 & 67 & 67 & 67 & 67 & 67 \\
\hline
\end{tabular}

Table 5. Mean concentrations for TCLP metals. Results in bold are greater than the EPA's CCC standard for that parameter. $\mathrm{NR}=$ not regulated by the EPA.

\begin{tabular}{cccccccc}
\hline & $\mathrm{Sb}$ & $\mathrm{As}$ & $\mathrm{Ba}$ & $\mathrm{Be}$ & $\mathrm{Cd}$ & $\mathrm{Cr}$ & $\mathrm{Pb}$ \\
\hline & $\mathrm{mg} / \mathrm{L}$ & $\mathrm{mg} / \mathrm{L}$ & $\mathrm{mg} / \mathrm{L}$ & $\mathrm{mg} / \mathrm{L}$ & $\mathrm{mg} / \mathrm{L}$ & $\mathrm{mg} / \mathrm{L}$ & $\mathrm{mg} / \mathrm{L}$ \\
\hline Sample value & $\mathbf{0 . 0 0 9}$ & 0.002 & 0.057 & 0.004 & 0.003 & 0.025 & $\mathbf{0 . 0 0 6}$ \\
EPA standard & 0.006 & 0.150 & 1.0 & 0.004 & 0.005 & 0.074 & 0.003 \\
\# of samples & 47 & 43 & 48 & 43 & 43 & 47 & 43 \\
\hline & & & & & & & \\
\hline & $\mathrm{Se}$ & $\mathrm{Ag}$ & $\mathrm{Cu}$ & $\mathrm{Ni}$ & $\mathrm{Tl}$ & $\mathrm{Zn}$ & $\mathrm{V}$ \\
\hline & $\mathrm{mg} / \mathrm{L}$ & $\mathrm{mg} / \mathrm{L}$ & $\mathrm{mg} / \mathrm{L}$ & $\mathrm{mg} / \mathrm{L}$ & $\mathrm{mg} / \mathrm{L}$ & $\mathrm{mg} / \mathrm{L}$ & $\mathrm{mg} / \mathrm{L}$ \\
\hline Sample value & 0.004 & $\mathbf{0 . 0 0 5}$ & $\mathbf{0 . 0 1 0}$ & 0.037 & 0.002 & 0.058 & 0.048 \\
EPA standard & 0.005 & 0.003 & 0.009 & 0.052 & 0.002 & 0.12 & $\mathrm{NR}$ \\
\# of samples & 43 & 43 & 43 & 48 & 43 & 47 & 47 \\
\hline
\end{tabular}

WVWRI tested for a wide variety of metals in the discharge water of the McCarty Highwall project. Of the tested parameters from Table 4, only $\mathrm{pH}, \mathrm{Al}$, and $\mathrm{Mn}$ were greater than the EPA 
CCC standards. It is to be expected that these parameters would have a greater concentration because they are typically elevated in acidic mine drainage. Thus, the most likely source for low $\mathrm{pH}$ and high concentrations of $\mathrm{Al}$ and $\mathrm{Mn}$ is the AMD and not the steel slag.

The TCLP metals that violated EPA CCC standards were $\mathrm{Sb}, \mathrm{Pb}, \mathrm{Ag}$, and $\mathrm{Cu}$ (Table 5). Various effects on human health could occur from exposure to toxic levels of these metals. Antimony raises cholesterol levels and lowers blood sugar levels, lead may delay development in children, and $\mathrm{Cu}$ causes kidney and liver damage (US EPA, 2003). Although $\mathrm{Sb}, \mathrm{Pb}, \mathrm{Ag}$, and $\mathrm{Cu}$ are in violation of EPA CCC standards (Table 5), it is unlikely that these violations are significant because the metal concentrations in the discharge water are very close to the EPA CCC standards. These results show that the AMD and TCLP metals are tightly bound within the steel slag matrix. Even in acidic environments, these metals are not significantly mobile in the environment.

\section{DeAntonis Property}

\section{$\underline{\text { Site Description }}$}

Morgan Run is located just south and east of Kingwood, WV. The DeAntonis site consisted of an abandoned mine portal that discharged into an area of ponded mine drainage that was parallel to an access road. The distance from the portal to the pond was 60 yards. A small freshwater channel also ran into the pond. The freshwater had a $\mathrm{pH}$ of 6.2 and a conductivity of $129 \mathrm{~ms} / \mathrm{cm}$. The combined flow discharged from the pond into a culvert under the road and then into Morgan Run. The distance from the pond discharge to Morgan Run was 75 yards.

Since freshwater was found on the site, steel slag was considered to be a good option for treatment of the AMD. There was also little room to construct passive treatment systems on the site. Efficient use of the existing land and water resources was very important in order to fully treat the discharge in the limited space allowed. Only passive treatment technologies were considered due to a lack of funding for continued operations and maintenance of active treatment. The portal drainage at this site had an acidity concentration of $871 \mathrm{mg} / \mathrm{L}$ as $\mathrm{CaCO}_{3}$, Fe concentrations of $190 \mathrm{mg} / \mathrm{L}$, and $\mathrm{Al}$ concentrations of $59 \mathrm{mg} / \mathrm{L}$. The amount of land required to treat a discharge with these chemical parameters with limestone alone is much larger than the available acreage at the project site. 
A treatment system for the DeAntonis project site was completed in August 2007. It consists of a steel slag leach bed, two collection ponds, as well as some open limestone channel. The project collects the AMD via a short open limestone channel (OLC) and directs it into a baffled retention pond. The drainage then flows into a second retention pond before discharging into another OLC and entering Morgan Run. The steel slag leach bed collects water from two surface freshwater sources and pipes it to a point just above the first retention pond in an effort to precipitate as much of the metals as possible. Figure 3 is a conceptual drawing of the treatment system and Fig. 4 is a picture of the steel slag leach bed as it was being constructed.

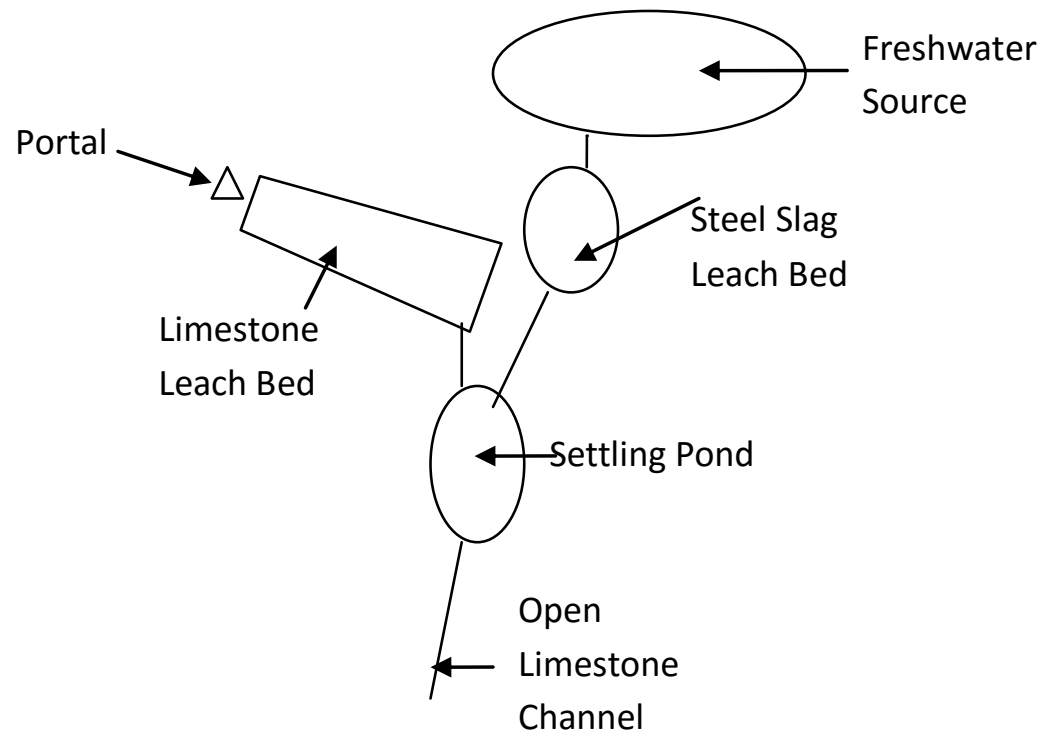

Figure 3. Conceptual drawing of the Morgan Run/DeAntonis AMD treatment project 


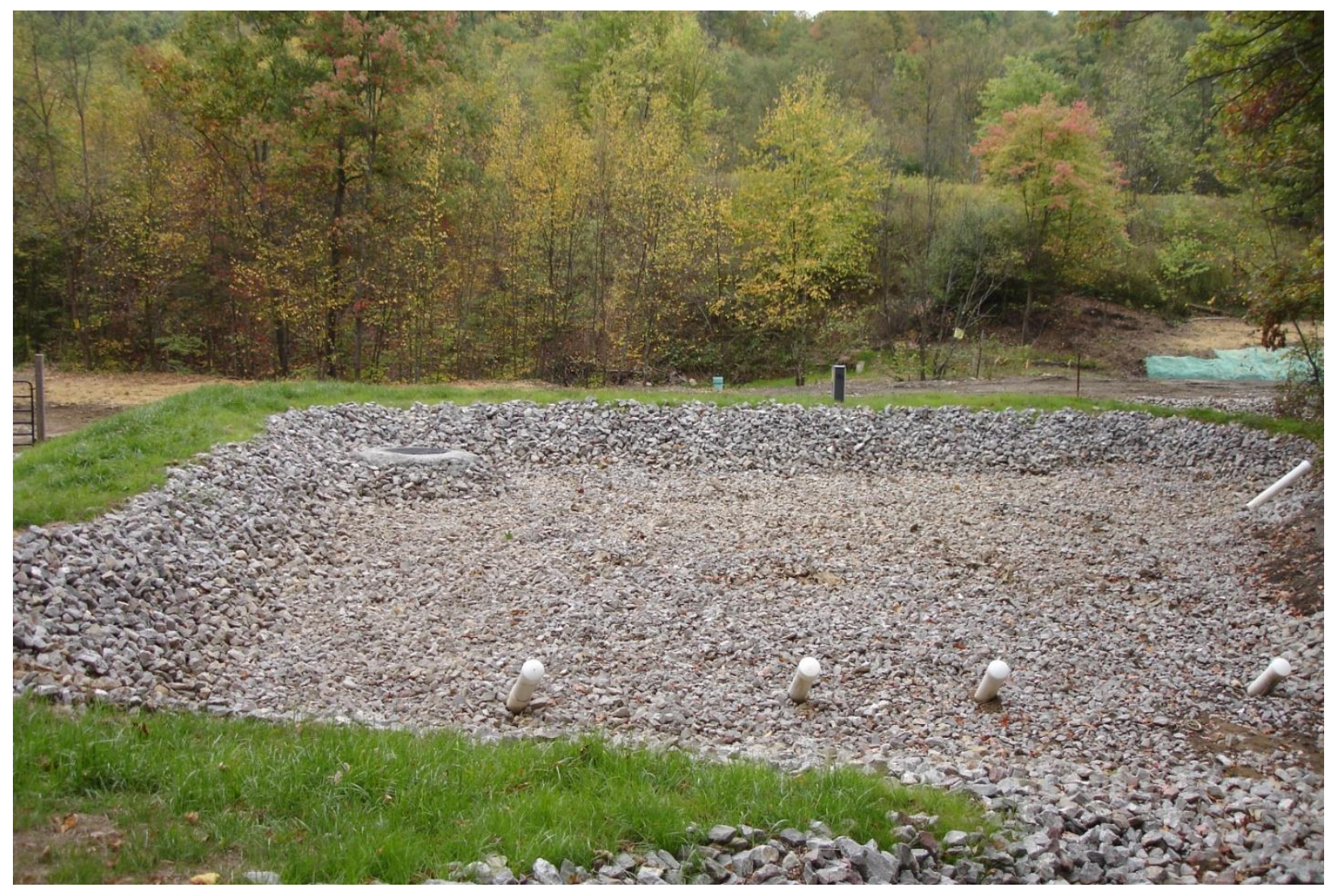

Figure 4. Steel slag leach bed under construction at the DeAntonis project site.

Similar to the McCarty Highwall site, post-construction water quality monitoring of traditional AMD parameters was performed at the DeAntonis project site. This sampling was performed using the same sampling methods as the McCarty Highwall site. However, TCLP parameters were not sampled. Table 6 shows post-construction water quality from the discharge point of the slag bed and Table 7 shows water quality from the discharge point of the entire project. Each of these sample points were compared against the EPA CCC standards. 
Table 6. Mean values for traditional AMD parameters at the inflow and discharge of the steel slag leach bed, except for $\mathrm{pH}$. The median value was used for $\mathrm{pH}$. Results in bold are greater/less than the EPA's CCC standard for that parameter. NR=not regulated by the EPA. NS=Not Sampled.

\begin{tabular}{ccccccccc}
\hline & Flow & $\mathrm{pH}$ & Acidity & Alkalinity & $\mathrm{SO}_{4}$ & $\mathrm{Fe}$ & $\mathrm{Al}$ & $\mathrm{Mn}$ \\
\hline & $\mathrm{gpm}$ & $\mathrm{SU}$ & $\mathrm{mg} / \mathrm{L}$ & $\mathrm{mg} / \mathrm{L}$ & $\mathrm{mg} / \mathrm{L}$ & $\mathrm{mg} / \mathrm{L}$ & $\mathrm{mg} / \mathrm{L}$ & $\mathrm{mg} / \mathrm{L}$ \\
\hline Fresh Water In & 72.2 & $\mathbf{6 . 2 8}$ & 52.1 & 20.4 & 64.9 & 0.7 & $\mathbf{0 . 3}$ & $\mathbf{0 . 1}$ \\
EPA standard & $\mathrm{NR}$ & $6.5-9$ & $\mathrm{NR}$ & 20 & 250 & 1.0 & 0.09 & 0.05 \\
\# of samples & 13 & 13 & 12 & 12 & 12 & 12 & 12 & 12 \\
& & & & & & & & \\
Slag Bed Out & $\mathrm{NS}$ & $\mathbf{1 1 . 8 1}$ & 0 & $\mathbf{8 5 . 9 6}$ & 33.9 & 0.4 & $\mathbf{0 . 3}$ & $<0.1$ \\
EPA standard & $\mathrm{NR}$ & $6.5-9$ & $\mathrm{NR}$ & 20 & 250 & 1.0 & 0.09 & 0.05 \\
\# of samples & 0 & 2 & 2 & 2 & 2 & 2 & 2 & 2 \\
\hline
\end{tabular}

Table 7. Mean values for traditional AMD parameters, except for $\mathrm{pH}$. The median value was used for $\mathrm{pH}$. Results in bold are greater/less than the EPA's CCC standard for that parameter. $\mathrm{NR}=$ Not Regulated by the EPA.

\begin{tabular}{ccccccccc}
\hline & Flow & $\mathrm{pH}$ & Acidity & Alkalinity & $\mathrm{SO}_{4}$ & $\mathrm{Fe}$ & $\mathrm{Al}$ & $\mathrm{Mn}$ \\
\hline & $\mathrm{gpm}$ & $\mathrm{SU}$ & $\mathrm{mg} / \mathrm{L}$ & $\mathrm{mg} / \mathrm{L}$ & $\mathrm{mg} / \mathrm{L}$ & $\mathrm{mg} / \mathrm{L}$ & $\mathrm{mg} / \mathrm{L}$ & $\mathrm{mg} / \mathrm{L}$ \\
\hline System Out & 231.2 & $\mathbf{3 . 1 7}$ & 460.1 & 0 & $\mathbf{4 8 7}$ & $\mathbf{5 3 . 4 5}$ & $\mathbf{2 2 . 7}$ & $\mathbf{1 . 6}$ \\
EPA standard & $\mathrm{NR}$ & $6.5-9$ & $\mathrm{NR}$ & 20 & 250 & 1.0 & 0.09 & 0.05 \\
\# of samples & 3 & 3 & 3 & 3 & 3 & 3 & 3 & 3 \\
\hline
\end{tabular}

The discharge water from the System Out sample point violated EPA CCC standards for $\mathrm{pH}$, sulfate, and metals (Table 7). This may partially be due to the small number of samples taken. However, the part of the system that used steel slag performed well. Concentrations of metals and sulfates were either slightly above or below EPA CCC standards (Table 6), with only Al a possible parameter of concern. The concentrations of metals in the discharge water also compared favorably with metal concentrations in the inflow water. In fact, metal concentrations were lower after the freshwater contacted the steel slag. These results provide further evidence that metals stay within the matrix of the steel slag and are not mobile in the environment. Steel slag is also shown to be an effective source of alkalinity, especially when used in direct contact with freshwater and not AMD. 


\section{Muzzleloader Club}

\section{$\underline{\text { Site Description }}$}

Lambert Run is an 8 square mile sub-watershed of the West Fork River watershed in Harrison County, West Virginia. The West Fork watershed comprises 880 square miles located in the north central portion of West Virginia. Its boundaries include all of Harrison County, most of Lewis County, and parts of Marion, Taylor, Barbour and Upshur Counties. The West Fork River flows 103 miles north through Weston and Clarksburg, to its confluence with the Tygart River near Fairmont, where the two form the Monongahela River. Clarksburg is the nearest, large city, about four miles to the southeast. The smaller communities of Hepzibah, Meadowbrook, and Spelter lie just outside the southeastern border of the Lambert Run watershed. US Route 19 also lies just outside the southeastern boundary of the watershed. Three water samples were collected at the Muzzleloader Property project site on Lambert Run. The objective of these sampling trips was to determine acid load emanating from the exposed portal and to see if the existing wetland was beneficial in reducing the acid load. Based upon these samples, the portal water demonstrated mildly acidic, metal laden acid mine drainage. The samples collected from the portal had an average acidity of $73 \mathrm{mg} / \mathrm{L}$ as $\mathrm{CaCO}_{3}$ with average metal concentrations of $13.3 \mathrm{mg} / \mathrm{L}$ of $\mathrm{Fe}, 2.37 \mathrm{mg} / \mathrm{L}$ of $\mathrm{Al}$, and a Mn concentration of $3.63 \mathrm{mg} / \mathrm{L}$. Figure 5 shows the conceptual design for the Muzzleloader Club project and Figure 6 shows the steel slag bed under construction. 


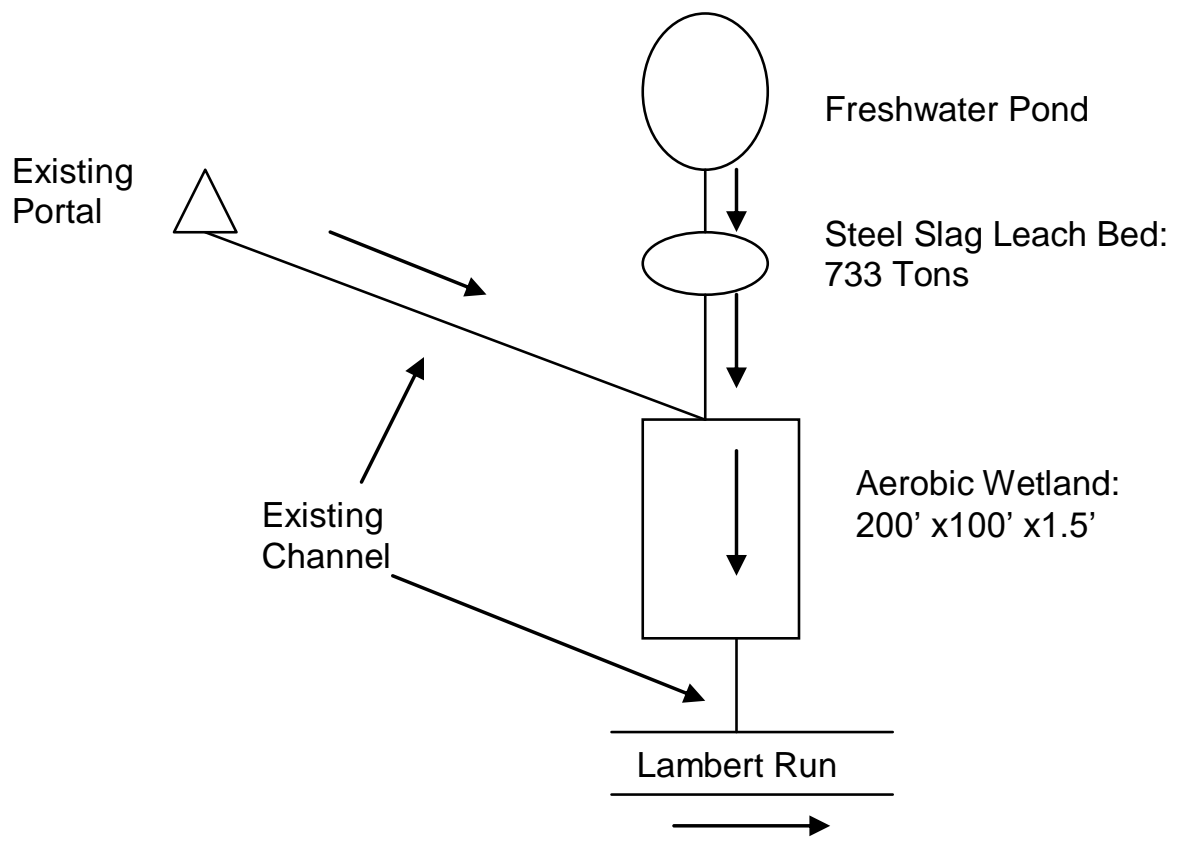

Figure 5. Conceptual design of the AMD treatment system at the Muzzleloader Club site. 


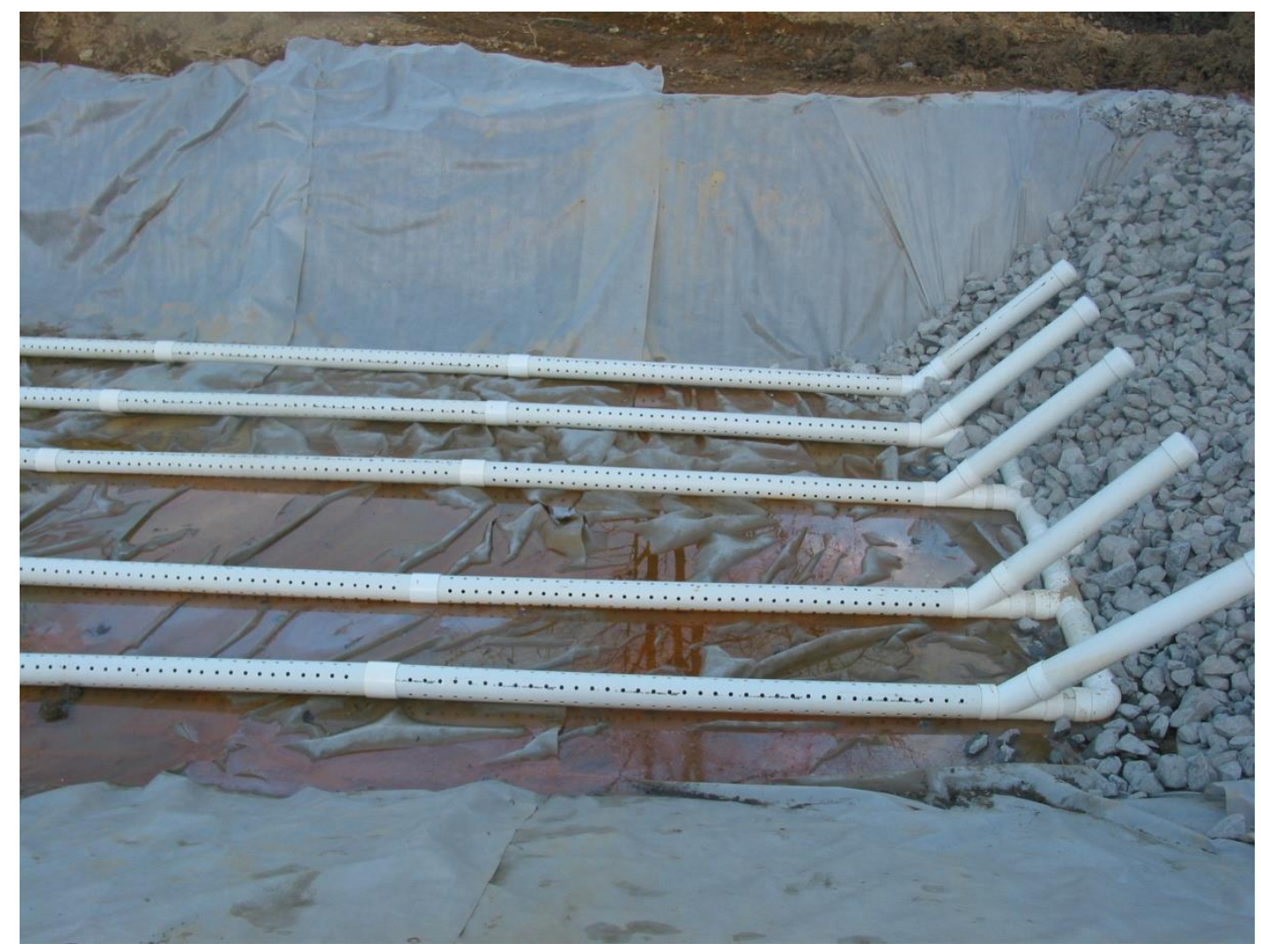

Figure 6. Steel slag leach bed under construction at the Muzzleloader Club site.

\section{Water quality}

Similar to the DeAntonis site on Morgan Run, steel slag was used in contact with fresh water at the Muzzleloader Club site. Water flowed from a pre-existing freshwater pond into a steel slag bed and then mixes with AMD-laden water. Because of the success found in using steel slag at the DeAntonis site on Morgan Run, it was assumed that slag would work well in the similar conditions found at the Muzzleloader Club site.

Similar to the two previously mentioned sites, post-construction water quality monitoring of traditional AMD parameters was performed at the Muzzleloader Club project site. Both traditional AMD parameters and TCLP parameters were sampled and analyzed using the same methods as the McCarty Highwall and DeAntonis projects. Traditional AMD parameters are given in Tables 8 and 9. Table 8 shows post-construction water quality from the discharge point of the slag bed and Table 9 gives water quality from the discharge point of the entire project (system out). Table 10 gives TCLP metal concentrations at both the discharge of the slag bed as 
well as the discharge of the entire project. Each of these sample points were compared against the EPA CCC standards.

Table 8. Mean values of traditional AMD parameters at the steel slag bed discharge point for the Muzzleloader Club project. Values in bold are above EPA CCC standards. $\mathrm{NR}=$ not regulated by the EPA.

\begin{tabular}{ccccccccc}
\hline & Flow & $\mathrm{pH}$ & Acidity & Alkalinity & $\mathrm{SO}_{4}{ }^{2-}$ & $\mathrm{Fe}$ & $\mathrm{Al}$ & $\mathrm{Mn}$ \\
\hline & $\mathrm{gpm}$ & $\mathrm{SU}$ & $\mathrm{mg} / \mathrm{L}$ & $\mathrm{mg} / \mathrm{L}$ & $\mathrm{mg} / \mathrm{L}$ & $\mathrm{mg} / \mathrm{L}$ & $\mathrm{mg} / \mathrm{L}$ & $\mathrm{mg} / \mathrm{L}$ \\
\hline Slag bed Out & 725.36 & 8.5 & 0.25 & $\mathbf{1 5 9 . 8 7}$ & 123.17 & 0.30 & 0.08 & $\mathbf{0 . 4 6}$ \\
EPA standard & $\mathrm{NR}$ & $6.5-9.0$ & $\mathrm{NR}$ & 20 & 250 & 1.0 & 0.09 & 0.05 \\
\# of samples & 3 & 6 & 5 & 3 & 3 & 4 & 4 & 4 \\
\hline
\end{tabular}

Table 9. Mean values of traditional AMD parameters at the system out discharge point for the Muzzleloader Club project. Values in bold are above EPA CCC standards. NR=not regulated by the EPA.

\begin{tabular}{ccccccccc}
\hline & Flow & $\mathrm{pH}$ & Acidity & Alkalinity & $\mathrm{SO}_{4}{ }^{2-}$ & $\mathrm{Fe}$ & $\mathrm{Al}$ & $\mathrm{Mn}$ \\
\hline & $\mathrm{gpm}$ & $\mathrm{SU}$ & $\mathrm{mg} / \mathrm{L}$ & $\mathrm{mg} / \mathrm{L}$ & $\mathrm{mg} / \mathrm{L}$ & $\mathrm{mg} / \mathrm{L}$ & $\mathrm{mg} / \mathrm{L}$ & $\mathrm{mg} / \mathrm{L}$ \\
\hline System Out & 340.00 & 8.31 & 1.53 & $\mathbf{4 4 . 0 9}$ & $\mathbf{4 6 3 . 6 7}$ & 0.95 & $\mathbf{0 . 1 7}$ & $\mathbf{1 . 4 2}$ \\
EPA standard & $\mathrm{NR}$ & $6.5-9$ & $\mathrm{NR}$ & 20 & 250 & 1.0 & 0.09 & 0.05 \\
\# of samples & 5 & 10 & 3 & 6 & 6 & 6 & 5 & 5 \\
\hline
\end{tabular}

Table 10. Mean concentrations of TCLP metals at the steel slag bed out discharge point for the Muzzleloader Club project. Values in bold are above EPA CCC standards. NR=not regulated by the EPA.

\begin{tabular}{ccccccccc}
\hline & $\mathrm{Sb}$ & $\mathrm{As}$ & $\mathrm{Ba}$ & $\mathrm{Be}$ & $\mathrm{Cd}$ & $\mathrm{Cl}$ & $\mathrm{Cr}$ & $\mathrm{Pb}$ \\
\hline & $\mathrm{mg} / \mathrm{L}$ & $\mathrm{mg} / \mathrm{L}$ & $\mathrm{mg} / \mathrm{L}$ & $\mathrm{mg} / \mathrm{L}$ & $\mathrm{mg} / \mathrm{L}$ & $\mathrm{mg} / \mathrm{L}$ & $\mathrm{mg} / \mathrm{L}$ & $\mathrm{mg} / \mathrm{L}$ \\
\hline Slag bed Out & $<0.035$ & $<0.047$ & 0.06 & $<0.01$ & $<0.014$ & $\mathbf{1 . 0 6}$ & $<0.012$ & $<0.032$ \\
EPA standard & 0.006 & 0.150 & 1.0 & 0.004 & 0.005 & 0.011 & 0.074 & 0.003 \\
\# of samples & 1 & 1 & 3 & 1 & 3 & 2 & 3 & 1 \\
\hline
\end{tabular}

\begin{tabular}{cccccccc}
\hline & $\mathrm{Se}$ & $\mathrm{Ag}$ & $\mathrm{Cu}$ & $\mathrm{Ni}$ & $\mathrm{Ti}$ & $\mathrm{Zn}$ & $\mathrm{V}$ \\
\hline & $\mathrm{mg} / \mathrm{L}$ & $\mathrm{mg} / \mathrm{L}$ & $\mathrm{mg} / \mathrm{L}$ & $\mathrm{mg} / \mathrm{L}$ & $\mathrm{mg} / \mathrm{L}$ & $\mathrm{mg} / \mathrm{L}$ & $\mathrm{mg} / \mathrm{L}$ \\
\hline Slag bed Out & $<0.045$ & $<0.045$ & $<0.015$ & $<0.019$ & $<0.14$ & $<0.016$ & 0.038 \\
EPA standard & 0.005 & 0.003 & 0.009 & 0.052 & 0.002 & 0.12 & $\mathrm{NR}$ \\
\# of samples & 1 & 1 & 3 & 3 & 1 & 3 & 1 \\
\hline
\end{tabular}


Most traditional AMD parameters were below EPA CCC standards at the steel slag bed out sampling point (Table 8). The only exception was Mn, which had a concentration of $0.46 \mathrm{mg} / \mathrm{L}$. The Mn standard of $0.05 \mathrm{mg} / \mathrm{L}$ is only applicable if the sample was taken within 0.5 miles of a drinking water source. This was not the case with this sample point.

Traditional AMD parameters were also sampled at the outfall of the Muzzleloader project. At this point, there were more parameters that were above EPA standards. These included sulfate, Al, and Mn. Although these three parameters were in violation of EPA's CCC standards, their concentrations would become diluted by the time the water from the Muzzleloader site reaches the West Fork River. It is also expected that these concentrations will decrease as wetland vegetation becomes established at the Muzzleloader project site.

The sample taken at the discharge of the steel slag bed was also analyzed for TCLP metal concentrations. Chlorine was the only analyzed parameter that was above the CCC standards set by the EPA. However, some of the parameters were below the detection limits of EPA method 200.7 (Table 10). The detection limits for the equipment used to analyze for these parameters is greater than the EPA CCC standards. Because of this issue, it cannot be known with certainty if this discharge violated EPA standards. Similar to the other two sites, the TCLP metals seemed to remain within the steel slag matrix and did not become mobile in the environment.

\section{$\underline{\text { Conclusion }}$}

Three passive treatment projects that used steel slag were evaluated to determine if possibly toxic metals found in trace concentrations would leach into the surrounding environment as the slag reacted. Only two of the three projects (McCarty and Muzzleloader) were sampled specifically for TCLP metals and compared against EPA CCC standards. Only four parameters at the McCarty Highwall site ( $\mathrm{Sb}, \mathrm{Pb}, \mathrm{Ag}$, and $\mathrm{Cu})$ and one parameter at the Muzzleloader Club site $(\mathrm{Cl})$ were found to be in violation of these standards. These results indicate that the metals found within the steel slag matrix are not mobile. However, monitoring of these three sites will continue to determine if discharge water from these steel slag leach beds may leach metals into their receiving streams over time.

Overall, we would recommend steel slag in the use of passive treatment. It is a relatively cheap source of alkalinity that increases $\mathrm{pH}$ quickly compared to limestone. It also does not require as much land area as conventional limestone-based passive treatment systems. The two major restrictions regarding steel slag use are that the slag should only be used to raise the $\mathrm{pH}$ of 
existing freshwater and the slag must remain submerged. The slag will harden into a concretelike substance (thus reducing porosity and area of the slag available for reaction) if these conditions are not followed.

A third possible restriction on the use of steel slag is what happens to it as it ages. The use of steel slag as an option for AMD treatment is a fledgling science, which means that many passive treatment systems that contain steel slag have not been installed long enough to know if more metals are released over an extended period of time. The McCarty Highwall project was the first steel slag project to be installed in West Virginia, and metal concentrations have remained low nine years after installation of the project. However, if these restrictions are taken into consideration during the design phase of a passive treatment system, steel slag can be a valuable addition to the design "toolbox" of AMD reclamationists.

\section{Literature cited}

Bowden, L., Johnson, K., Jarvis, A., Robinson, H., Ghazireh, N, and Younger, P. 2006, The use of Basic Oxygen Steel Furnace slag (BOS) as a high surface area media for the removal of iron from circum-neutral mine waters, 7th International Conference on Acid Rock Drainage, 2006 pp 234-246 http://dx.doi.org/10.21000/jasmr06020234

Buchanan, T.J. and Somers, W. P. 1976. Discharge measurements at gauging stations. Chap. A8, p. 32-33 In Techniques of Water-Resources Investigations of the United States Geological Survey, Book 3; Application of Hydraulics. USGS, Washington D.C.

Chaurand, P., Rose, J., Briois, V., Olivi, L., Hazemann, J., Proux, O., Domas, J., and Bottero, J. 2006. Environmental impacts of steel slag reused in road construction: a crystallographic and molecular (XANES) approach. Journal of Hazardous Materials 139 (3): 537-542. http://dx.doi.org/10.1016/j.jhazmat.2006.02.060.

Cravotta, C.A., III, 2005, Assessment of characteristics and remedial alternatives for abandoned mine drainage: case study at Staple Bend Tunnel Unit of Allegheny Portage Railroad National Historic Site, Cambria County, Pennsylvania, 2004: USGS Open-File Report 20051283, 52 p. (http://pubs.usgs.gov/of/2005/1283/ofr2005-1283.pdf)

Fallman, A. 2000. Leaching of chromium and barium from steel slag in laboratory and field tests-a solubility-controlled process? Waste Management 20: 149-154. http://dx.doi.org/10.1016/S0956-053X(99)00313-X54. 
Gomes, J. and Pinto, C. 2006. Leaching of heavy metals from steelmaking slags. Revista del Metalurgia 42(6): 409-416. http://dx.doi.org/10.3989/revmetalm.2006.v42.i6.39.

Hamilton, J., Gue, J., and Socotch, C. 2007. The use of steel slag in passive treatment design for AMD discharges in the Huff Run watershed restoration. Proceedings of the 28th West Virginia Mine Drainage Task Force Symposium. April 10-11, 2007. Morgantown, WV. http://dx.doi.org/10.21000/jasmr07010272.

Laverty, B., McCament, B., and Farley, M. 2007. Performance of steel slag and other passive treatment systems at the Broken Aro mine in Little Raccoon Creek, Ohio. Proceedings of the $28^{\text {th }}$ West Virginia Mine Drainage Task Force Symposium. April 10-11, 2007. Morgantown, WV.

Proctor, D., Shay, E., Fehling, K., and Finley, B. 2002. Assessment of human health and ecological risks posed by the uses of steel industry slags in the environment. Human and Ecological Risk Assessment 8: 681-711. http://dx.doi.org/10.1080/108070302908799071.

Proctor, D., Fehling, K., Shay, E., Wittenborn, J., Green, J., Avent, C., Bigham, R., Connolly, M., Lee, B., Shepker, T., and Zak, M. 2000. Physical and chemical characteristics of Blast Furnace, Basic Oxygen Furnace, and Electric Arc Furnace steel industry slags. Environ. Sci. Technol. 34: 1576-1582. http://dx.doi.org/10.1021/es99060022.

Simmons, J., Ziemkiewicz, P., and Black, D. C. 2002. Use of steel slag leach beds for the treatment of acid mine drainage. Mine Water and the Environment 21: 91-99. http://dx.doi.org/10.1007/s102300200024.

U.S. Environmental Protection Agency. 1992. EPA Test Method 1311 - TCLP, Toxicity Characteristic Leaching Procedure. 38 p. (http://www.ehso.com/cssepa/TCLP_from\%20EHSOcom_Method_1311.pdf)

U.S. Environmental Protection Agency. 2002. National recommended water quality criteria2002: U.S. Environmental Protection Agency EPA 822-R-02-047, 33 p. (http://www.epa.gov/ost/pc/revcom.pdf)

U.S. Environmental Protection Agency. 2003. National primary drinking water standards. U.S. EPA 846-F-03-016, 6 p. (http://www.epa.gov/safewater/consumer/pdf/mcl.pdf)

Ziemkiewicz, P. 1998. Steel slag: applications for AMD control. Proceedings of the 1998 conference on Hazardous Waste Research. May 19-21, 1998. Snow Bird, Utah. 
Ziemkiewicz, P. and Skousen, J. 1998. The use of steel slag in acid mine drainage treatment and control In Proceedings of the 1998 West Virginia Surface Mine Drainage Task Force Symposium. April 7-8, 1998. Morgantown, WV. 